\title{
Occurrence, Pathogenicity and Assessment of Groundnut Genotypes Resistance to Aspergillus niger Inciting Collar Rot Disease
}

\author{
C. Vimal Kumar ${ }^{1 *}$, M. Saifulla ${ }^{2}$, Madem Gurivi Reddy ${ }^{1}$, \\ R. Naveenkumar ${ }^{3}$ and S. R. Prabhukarthikeyan ${ }^{3}$
}

${ }^{I}$ Division of Plant Pathology, Indian Agricultural Research Institute, Pusa Campus, New Delhi, India

${ }^{2}$ Department of Plant Pathology, GKVK, Bangalore, Karnataka, India

${ }^{3}$ Crop Protection Division, ICAR-National Rice Research Institute, Cuttack, India

*Corresponding author

\section{A B S T R A C T}

\begin{tabular}{|l|}
\hline Ke y w or d s \\
Groundnut \\
Genotypes, \\
Aspergillus niger \\
\hline Article Info \\
\hline $\begin{array}{l}\text { Accepted: } \\
\text { 07 October } 2020 \\
\text { Available Online: } \\
10 \text { November } 2020\end{array}$ \\
\hline
\end{tabular}

\begin{abstract}
A survey was conducted for collar rot disease incidence in southern Karnataka showed that Tumkur district recorded highest collar rot disease incidence of 14 percent followed by Chamarajanagar $(8.50 \%)$ whereas Kolar recorded least disease incidence of 3.3 percent in Kharif. During summer 3.3 percent disease incidence was observed in Davangere district. Collar rot of groundnut pathogen was isolated by following standard tissue isolation method and the culture was identified through morphological and cultural characters. Pathogenicity was proved by blotter paper technique and sick pot method and the culture was compared with original culture. Among sixty four genotypes screened for collar rot, five genotypes viz., ICG 1994, ICG 2734, ICG 4749, ICG 13856 and ICG 7190 showed moderately resistant reactions. K-6 recorded least percent disease incidence $(1.0 \%)$ with highest pod yield of $10.5 \mathrm{q} / \mathrm{ha}$ compared to control TMV 2 with more disease incidence $(2.30 \%)$ and less pod yield of $(7.7 \mathrm{q} / \mathrm{ha})$.
\end{abstract}

\section{Introduction}

Groundnut (Arachis hypogaea L.) is a very important legume crop of tropical and subtropical areas of the world and cultivation of this crop is mostly confined to the geographical belt between $40^{\circ} \mathrm{N}$ and $40^{\circ} \mathrm{S}$ latitude (Pattee and Young, 1982). In India, it is one of the most important oilseed crop and regarded as 'king of oilseeds'. Globally groundnut is grown in 25.46 million ha, with the production of 45.30 million tons and with productivity of $1780 \mathrm{~kg} / \mathrm{ha}$. China ranks first in world with production of 16.91 million tons from 4.6 million ha of cultivated area with the productivity of $3614 \mathrm{~kg} / \mathrm{ha}$. India is one of the leading country in the production of groundnut in the world followed by China with production of 9.47 million tons from 5.25 million ha of cultivated area with productivity of $1804 \mathrm{~kg} / \mathrm{ha}$ (Anon, 2014). The cultivation of crop was affected by many biotic and abiotic stresses (Muthukumar et al., 2014). Among biotic stresses, groundnut is 
attacked by many fungal, bacterial and viral pathogens. The most economically important fungal diseases are tikka, rust, stem rot, collar rot and various other soil borne diseases have also been reported which causes severe damage to the crop (Desai and Bagwan, 2005). Collar rot caused by Aspergillus niger van Teighem is one of the most important disease of groundnut which is more extensive in the kharif than the rabi and summer seasons and causes more damage in sandy loam and medium black soil. Annual world yield loss caused by collar rot is more than 10 per cent (Pande and Rao, 2000) and is more prevalent in soils with low moisture content and high temperature, approximately $30^{\circ} \mathrm{C}$ (Kishore et al., 2007). A. niger causing collar rot disease on groundnut seedlings was first reported by Jochem (1926). However, Jain and Nema, (1952) first reported from India. This disease appears in two phases, viz., preemergence and post-emergence phase. In the pre-emergence phase, the seed may rot in the soil or be covered with black masses of spore on germination; the emerging hypocotyls are rapidly killed by these spores. In the postemergence phase, circular light brown lesions appear initially on the cotyledons and as these advances the hypocotyls tissue or stem lesions become water-soaked and show light brown discoloration. The seedlings then collapse and die due to the rotting of the succulent hypocotyls. The loss due to this disease was reported up to 40-50 percent (Chahal et al., 1974).

Since, chemical, biological and cultural practices had been followed to manage the soil borne pathogens (Krishnakanth et al., 1999, Prabhukarthikeyan et al., 2014; 2017; 2018; 2019). Persistence of the pathogen in soil and its wide range of host might often limits the effectiveness of the chemical and cultural management of soil borne pathogens (Palaiah et al., 2019). However, partial resistant varieties in comparison to susceptible one, has better resistance efficiency (Shew et al., 1984). Therefore, systematic screening of various groundnut germplasm lines for identifying resistant sources will help in identification of elite lines with superior resistance to these diseases. Hence the present study was taken up to assess the prevalence and incidence of collar rot of groundnut in south Karnataka, India and to identify the resistance against collar rot and stem rot pathogens.

\section{Materials and Methods}

\section{Survey of collar rot incidence on groundnut from south Karnataka}

An intensive survey was conducted on the incidence of the disease in major groundnut growing areas of southern Karnataka viz., Chamarajanagar, Chikkaballapur, Chitradurga, Davangere, Kolar and Tumkur districts. The roving survey was employed to assess the disease incidence. The information about cultivar grown, age of the plant, sole or mixed crop and previous crop were recorded during survey. The total number of plant present and number of plants showing disease symptoms due to the Aspergillus niger in each plot were counted and recorded. The percent disease incidence was calculated by using the following formula.

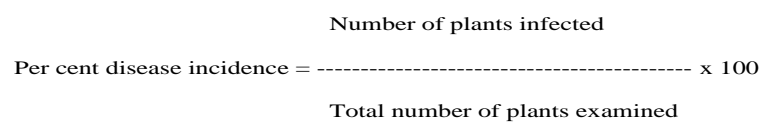

\section{Isolation of the $A$. niger}

Groundnut plants showing typical collar rot symptoms were collected from different parts of southern parts Karnataka. The isolation of fungus was done following standard tissue isolation technique. Those parts of root and collar showing typical symptoms of disease were washed in running tap water and cut into 
small bits. These bits were surface sterilized with 0.5 percent sodium hypochlorite solution for 30 seconds. The bits were washed thoroughly in sterile distilled water for 3-4 times to remove traces of sodium hypochlorite and then aseptically transferred to sterilized potato dextrose agar (PDA) plates and were incubated at $27 \pm 1^{\circ} \mathrm{C}$ for three days for growth of fungus. Later, the bit of fungal growth was transferred to PDA slants.

\section{Mass multiplication}

Sorghum seeds were used for the multiplication of $A$. niger. Two hundred and fifty grams of sorghum seeds in autoclavable Polypropylene covers and hundred grams of seeds in conical flask were saturated 20 percent of its weight and sterilized at 1.1 $\mathrm{kg} / \mathrm{cm} 2$ pressure for 20 minutes. The bits of pure cultured mycelium were placed in the substrate filled Polypropylene covers and conical flask under aseptic condition and both were incubated at $27 \pm 1^{\circ} \mathrm{C}$ for 15 days. These seeds were shaken periodically to get uniform growth of fungus.

\section{Pathogenicity test}

\section{Sick pot technique}

Twenty days old culture of $A$. niger grown on sorghum seeds were mixed with sterilized soil separately at three percent $\mathrm{w} / \mathrm{w}$ basis. Then apparently healthy surface sterilized groundnut seeds were sown in pots. Seeds sown in pots without inoculum served as control. Soil moisture was maintained approximately at field capacity by adding water at regular intervals. Observations were recorded regularly for the appearance and development of symptoms. The fungus were re-isolated from infected portion of the plant tissue and compared with that of original isolate.

\section{Blotter paper technique}

Blotting paper were cut into circles of $9 \mathrm{~cm}$ diameter and sterilized at $1.045 \mathrm{~kg} / \mathrm{cm}^{2}$ for 15 minutes. Three circles of blotting papers were placed at the bottom of sterilized Petri dishes aseptically and moistened by sterilized distilled water. Seeds were placed at an equal distance in each Petri dish. These dishes were incubated at $27 \pm 1^{\circ} \mathrm{C}$ with 12 hours of light alternating with 12 hours of dark period. The seeds were examined after 7 days of incubation.

\section{Screening for groundnut genotypes against collar rot disease}

\section{Soil inoculation technique}

The A. niger grown on sorghum seeds medium were maintained at $27 \pm 1^{\circ} \mathrm{C}$ for 15 days was used for the soil inoculation. The mass multiplied culture which was maintained on sorghum seeds were mixed with sterilized soil. Prior to sowing, pots were sterilized with copper sulphate solution and filled with pathogen inoculated sick soil.

\section{Screening under glasshouse condition}

A total of sixty four genotypes were screened for their relative resistance against collar rot disease under sick pot condition in glasshouse. Four seeds of each genotype were sown in individual pots, CRD design was employed and replicated thrice. Observation regarding pre-emergent rot, post-emergent rot and collar rot was taken up to pod formation stage at 10 days interval. Finally disease incidence was calculated based on final observation

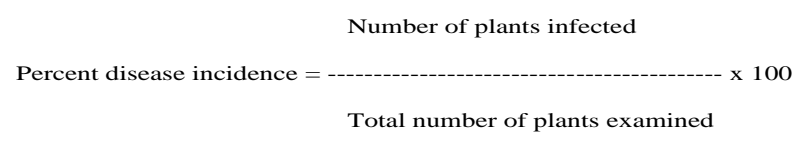




\section{Screening under field condition}

A total of seven cultivars were screened against collar rot in ARS, Rajavanthi, Pavagada. An observation on percent disease incidence was recorded at regular interval of time till pod formation stage. After estimating disease incidence the cultivars were categorized into different groups based on disease reaction viz., immune, resistant, moderately resistant, moderately susceptible, susceptible, highly susceptible (disease rating $0,1,3,5,7$ and 9 respectively) as per (Mayee and Datar, 1986).

\section{Statistical analysis}

The data were statistically analyzed using the IRRISTAT version 92 developed by the International Rice Research Institute Biometrics unit, the Philippines (Gomez and Gomez, 1984).

\section{Results and Discussion}

\section{Survey for collar rot of groundnut disease incidence in southern district of Karnataka}

Survey was under taken in both Kharif and summer season, whereas disease was more during Kharif compared to summer. During Kharif 2016 the collar rot incidence was varied from 3.3 to 14 percent. However, in summer disease incidence was 3.3 percent (Table 1 and Table 2). Among the districts, highest mean incidence of 14 percent was recorded in Tumkur with a range of $(12.50 \%$ $17.00 \%$ ) in Venkatapura and Rajavanthi villages of Pavagada taluk, followed by Chamarajanagar (8.50\%), Chitradurga $(6.40 \%)$ with a range of $(3.5 \%-12.0 \%)$ in Vadanahalli and Siddeshwaradurga villages of Hiriyur and Challekere taluk, Chikkaballapur $(6.15 \%)$ with a range of (2.0\%-14.0\%) in Gudibande (taluk) and Mindgall village of Chintamani taluk and
Kolar (3.30\%) with a range of $(0.0 \%-7.0 \%)$ in Agara and Adugodi villages of Mulbagl taluk. During summer 3.3 percent disease incidence was recorded in Davangere with a range of (0.0\%-5.0\%) in Lokikere and Linganahalli villages of Davangere and Jagalur taluk. This wide variation in disease incidence was due to the change in the environment conditions, pathogen inoculum in soil, variation in date of sowing, cultural practices followed and cultivars used.

\section{Isolation and identification of collar rot pathogen}

Collar rot infected samples were collected from farmer's field in Tumkur and the pathogen was isolated by following standard tissue isolation method. The pure culture obtained was sub-cultured on Petri plate and slants containing potato dextrose agar stored in refrigerator for use in further studies. A. niger sub-cultured isolate was identified morphologically on the culture plates showing initially white to yellowish felt-like mat of mycelia, quickly turning black as conidia develop the pigment aspergillin during maturation. Further studies were conducted by examining the type of conidiophore branching, conidia texture, colour and vesicle shape, checking for the presence of biserrate form in $A$. niger through compound microscope. Observations under microscope showed that mycelia were septate, hyaline and conidiophores (Stipes) were long with spherical vesicles at the apex.

They were showing biserrate form, metulae was about to cover the entire surface from which the phialides extended. Conidia were globose, brown to black in colour and had rough surface (Figure 1). Based on the above cultural characters, morphological characters, and the growth of the fungus on media, the pathogen was identified as Aspergillus niger. 
Table.1 Survey for collar rot disease incidence of groundnut in different districts of southern Karnataka in Kharif 2016-2017

\begin{tabular}{|c|c|c|c|c|c|}
\hline SI.No. & District & Taluk & Villages & Per cent disease incidence & District mean \\
\hline 1 & Chamarajanagara & Chamarajanagara & Hardnahalli & 8.5 & $8.5 \%$ \\
\hline \multirow[t]{11}{*}{2} & \multirow{11}{*}{ Chitradurga } & \multirow{7}{*}{ Challakere } & Belegere & 7.0 & \multirow{11}{*}{$6.4 \%$} \\
\hline & & & Heggere & 5.0 & \\
\hline & & & Kadegude & 8.0 & \\
\hline & & & Katamdevarakote & 6.0 & \\
\hline & & & Parasuramapura & 10 & \\
\hline & & & Siddeswaranadurga & 12 & \\
\hline & & & Mean & $8.0 \%$ & \\
\hline & & \multirow[t]{4}{*}{ Hiryur } & Kasturirangappenahalli & 6.0 & \\
\hline & & & Rayabommanahalli & 5.0 & \\
\hline & & & Vadanahalli & 3.5 & \\
\hline & & & Mean & $4.8 \%$ & \\
\hline \multirow[t]{13}{*}{3} & \multirow[t]{11}{*}{ Chikkaballapur } & \multirow[t]{6}{*}{ Chintamani } & Munganahalli & 8.5 & \multirow[t]{11}{*}{$6.15 \%$} \\
\hline & & & Siddepalli & 8.0 & \\
\hline & & & Gudisalahalli & 4.5 & \\
\hline & & & Mindgall & 14.0 & \\
\hline & & & Mittahalli & 6.0 & \\
\hline & & & Mean & $8.2 \%$ & \\
\hline & & \multirow[t]{4}{*}{ Bagepalli } & Nadampalli & 9.0 & \\
\hline & & & Chelur & 4.0 & \\
\hline & & & Pathapalya & 8.0 & \\
\hline & & & Mean & $7 \%$ & \\
\hline & & Gudibande & Gudibande & 2.0 & \\
\hline & & & Molanhalli & 4.5 & \\
\hline & & & Mean & $3.25 \%$ & \\
\hline \multirow[t]{5}{*}{4} & \multirow{5}{*}{ Kolar } & \multirow{5}{*}{ Mulbagal } & Audgodi & 7.0 & \multirow{5}{*}{$3.3 \%$} \\
\hline & & & Ramarayanakote & 5.0 & \\
\hline & & & Tayalur & 1.5 & \\
\hline & & & Agara & 0.0 & \\
\hline & & & Mean & $3.3 \%$ & \\
\hline \multirow[t]{6}{*}{5} & \multirow[t]{6}{*}{ Tumkur } & \multirow[t]{6}{*}{ Pavagada } & Rajavanthi & 17.0 & \multirow[t]{6}{*}{$14 \%$} \\
\hline & & & Macharajanahalli & 14.5 & \\
\hline & & & Dommathamari & 13.0 & \\
\hline & & & Neralekunte & 13.0 & \\
\hline & & & Venkatapura & 12.5 & \\
\hline & & & Mean & $14 \%$ & \\
\hline
\end{tabular}

Table.2 Survey for collar rot disease incidence of groundnut in district of southern Karnataka during summer 2016-2017

\begin{tabular}{|c|c|c|c|c|c|}
\hline Sl.No. & District & Taluk & Villages & $\begin{array}{l}\text { Per cent } \\
\text { disease } \\
\text { incidence }\end{array}$ & $\begin{array}{c}\text { District } \\
\text { mean }\end{array}$ \\
\hline \multirow[t]{6}{*}{1} & \multirow[t]{6}{*}{ Davangere } & \multirow[t]{5}{*}{ Davangere } & Belavanur & 3.5 & \multirow[t]{6}{*}{$3.3 \%$} \\
\hline & & & Lokikere & 0.0 & \\
\hline & & & Hadadi & 2.0 & \\
\hline & & & Naganoor & 1.0 & \\
\hline & & & Mean & $1.6 \%$ & \\
\hline & & Jagalur & Linganahalli & 5.0 & \\
\hline
\end{tabular}


Table.3 Screening for genotypes against collar rot disease in glass house condition

\begin{tabular}{|c|c|c|c|c|c|c|c|}
\hline Sl.No. & Genotypes & Germination (\%) & $\begin{array}{l}\text { Pre-emergent } \\
\text { collar rot }(\%)\end{array}$ & $\begin{array}{l}\text { Post-emergent } \\
\text { collar rot }(\%)\end{array}$ & $\begin{array}{l}\text { Collar rot } \\
(\%)\end{array}$ & $\begin{array}{l}\text { Total Disease } \\
\text { incidence }(\%)\end{array}$ & $\begin{array}{l}\text { Disease } \\
\text { reaction }\end{array}$ \\
\hline 1 & ICG 188 & 58.33 & 41.67 & 0.00 & 25 & 100.00 & HS \\
\hline 2 & ICG 1173 & 33.33 & 66.67 & 0.00 & 0.00 & 66.67 & HS \\
\hline 3 & ICG 1323 & 83.33 & 16.67 & 0.00 & 16.67 & 33.34 & $\mathrm{~S}$ \\
\hline 4 & ICG 1326 & 75.00 & 25.00 & 0.00 & 0.00 & 25.00 & S \\
\hline 5 & ICG 1435 & 66.67 & 33.33 & 0.00 & 0.00 & 33.33 & $\mathrm{~S}$ \\
\hline 6 & ICG 1859 & 100.00 & 0.00 & 16.67 & 8.33 & 25.00 & S \\
\hline 7 & ICG 1994 & 91.67 & 8.33 & 0.00 & 0.00 & 8.33 & MR \\
\hline 8 & ICG 2734 & 91.67 & 8.33 & 0.00 & 0.00 & 8.33 & MR \\
\hline 9 & ICG 2738 & 33.33 & 66.67 & 33.33 & 0.00 & 100.00 & HS \\
\hline 10 & ICG 3120 & 58.33 & 41.67 & 0.00 & 0.00 & 41.67 & $\mathrm{~S}$ \\
\hline 11 & ICG 3263 & 75.00 & 25.00 & 8.33 & 8.33 & 41.67 & S \\
\hline 12 & ICG 3336 & 58.33 & 41.67 & 0.00 & 0.00 & 41.67 & S \\
\hline 13 & ICG 3700 & 58.33 & 41.67 & 0.00 & 0.00 & 41.67 & S \\
\hline 14 & ICG 4343 & 33.33 & 66.67 & 0.00 & 0.00 & 66.67 & HS \\
\hline 15 & ICG 4389 & 8.33 & 91.67 & 0.00 & 0.00 & 91.67 & HS \\
\hline 16 & ICG 4412 & 33.33 & 66.67 & 16.67 & 8.33 & 91.67 & HS \\
\hline 17 & ICG 4527 & 41.67 & 58.33 & 8.33 & 0.00 & 66.66 & HS \\
\hline 18 & ICG 4589 & 83.33 & 16.67 & 0.00 & 0.00 & 16.67 & MS \\
\hline 19 & ICG 4601 & 41.67 & 58.33 & 0.00 & 0.00 & 58.33 & HS \\
\hline 20 & ICG 4749 & 100.00 & 0.00 & 0.00 & 8.33 & 8.33 & MR \\
\hline 21 & ICG 4750 & 58.33 & 41.67 & 0.00 & 0.00 & 41.67 & $\mathrm{~S}$ \\
\hline 22 & ICG 4888 & 25.00 & 75.00 & 0.00 & 0.00 & 75.00 & HS \\
\hline 23 & ICG 4998 & 41.67 & 58.33 & 25 & 0.00 & 83.33 & HS \\
\hline 24 & ICG 6407 & 8.33 & 91.67 & 0.00 & 0.00 & 91.67 & HS \\
\hline 25 & ICG 7000 & 58.33 & 41.67 & 0.00 & 0.00 & 41.67 & $\mathrm{~S}$ \\
\hline 26 & ICG 7181 & 91.67 & 8.33 & 0.00 & 8.33 & 16.66 & MS \\
\hline 27 & ICG 7190 & 91.67 & 8.33 & 0.00 & 0.00 & 8.33 & MR \\
\hline 28 & ICG 7243 & 66.67 & 33.33 & 0.00 & 0.00 & 33.33 & $\mathrm{~S}$ \\
\hline 29 & ICG 7412 & 83.33 & 16.67 & 0.00 & 0.00 & 16.67 & MS \\
\hline 30 & ICG 7633 & 91.67 & 8.33 & 8.33 & 25 & 41.66 & $\mathrm{~S}$ \\
\hline 31 & ICG 8666 & 66.67 & 33.33 & 58.33 & 0.00 & 91.66 & HS \\
\hline 32 & ICG 9610 & 58.33 & 41.67 & 0.00 & 0.00 & 41.67 & $\mathrm{~S}$ \\
\hline 33 & ICG 9841 & 0.00 & 100.00 & 0.00 & 0.00 & 100.00 & HS \\
\hline
\end{tabular}




\begin{tabular}{|c|c|c|c|c|c|c|c|}
\hline 34 & ICG 10020 & 58.33 & 41.67 & 0.00 & 0.00 & 41.67 & $\mathrm{~S}$ \\
\hline 35 & ICG 10094 & 91.67 & 8.33 & 0.00 & 8.33 & 16.66 & MS \\
\hline 36 & ICG 10479 & 41.67 & 58.33 & 0.00 & 0.00 & 58.33 & $\mathrm{HS}$ \\
\hline 37 & ICG 10933 & 66.67 & 33.33 & 25 & 0.00 & 58.33 & $\mathrm{HS}$ \\
\hline 38 & ICG 11426 & 0.00 & 100.00 & 0.00 & 0.00 & 100.00 & HS \\
\hline 39 & ICG 12370 & 66.67 & 33.33 & 58.33 & 8.33 & 99.99 & HS \\
\hline 40 & ICG 13856 & 91.67 & 8.33 & 0.00 & 0.00 & 8.33 & $\mathrm{MR}$ \\
\hline 41 & ICG 14985 & 33.33 & 66.67 & 0.00 & 0.00 & 66.67 & HS \\
\hline 42 & ICG 87264 & 33.33 & 66.67 & 0.00 & 0.00 & 66.67 & HS \\
\hline 43 & ICG 95419 & 33.33 & 66.67 & 0.00 & 8.33 & 75.00 & HS \\
\hline 44 & ICGV 87165 & 0.00 & 100.00 & 0.00 & 0.00 & 100.00 & HS \\
\hline 45 & ICGV 91114 & 50.00 & 50.00 & 0.00 & 0.00 & 50.00 & S \\
\hline 46 & ICGV 903021 & 41.67 & 58.33 & 33.33 & 0.00 & 91.66 & HS \\
\hline 47 & GKVK 2 & 66.67 & 33.33 & 8.33 & 16.67 & 58.33 & $\mathrm{HS}$ \\
\hline 48 & GKVK 4 & 50.00 & 50.00 & 0.00 & 8.33 & 58.33 & HS \\
\hline 49 & GKVK 5 & 50.00 & 50.00 & 0.00 & 0.00 & 50.00 & S \\
\hline 50 & GKVK 8a & 83.33 & 16.67 & 66.67 & 0.00 & 83.34 & $\mathrm{HS}$ \\
\hline 51 & GKVK $8 b$ & 66.67 & 33.33 & 33.33 & 16.67 & 83.33 & HS \\
\hline 52 & GKVK 12 & 75.00 & 25.00 & 25 & 0.00 & 50.00 & $\mathrm{~S}$ \\
\hline 53 & GKVK 17 & 66.67 & 33.33 & 0.00 & 0.00 & 33.33 & $\mathrm{~S}$ \\
\hline 54 & KCG 6 & 41.67 & 58.33 & 25 & 0.00 & 83.33 & HS \\
\hline 55 & KCG 9 & 41.67 & 58.33 & 0.00 & 0.00 & 58.33 & HS \\
\hline 56 & AVK-2015-9 & 41.67 & 58.33 & 8.33 & 0.00 & 66.66 & $\mathrm{HS}$ \\
\hline 57 & TMV-2 & 66.67 & 33.33 & 58.33 & 8.33 & 99.99 & $\mathrm{HS}$ \\
\hline 58 & AVK-2015-12 & 33.33 & 66.67 & 0.00 & 25 & 91.67 & HS \\
\hline 59 & ISK-1-2014-15 & 25.00 & 75.00 & 0.00 & 0.00 & 75.00 & HS \\
\hline 60 & ISK-1-2015-5 & 8.33 & 91.67 & 0.00 & 8.33 & 100.00 & HS \\
\hline 61 & ISK-1-2015-8 & 33.33 & 66.67 & 8.33 & 0.00 & 75.00 & $\mathrm{HS}$ \\
\hline 62 & ISK-1-2015-9 & 16.67 & 83.33 & 0.00 & 0.00 & 83.33 & HS \\
\hline 63 & ISK-1-2015-10 & 50.00 & 50.00 & 16.67 & 16.67 & 83.34 & $\mathrm{HS}$ \\
\hline 64 & ISK-1-2015-11 & 25.00 & 75.00 & 16.67 & 0.00 & 91.67 & $\mathrm{HS}$ \\
\hline 65 & TMV 2 (Control) & 100.00 & 0.00 & 0.00 & 0.00 & 0.00 & - \\
\hline
\end{tabular}


Table.4 Disease reaction of groundnut genotypes for collar rot disease under glasshouse condition

\begin{tabular}{|c|c|c|c|}
\hline Scale & Reaction & Genotypes & $\begin{array}{c}\text { No. of } \\
\text { genotype }\end{array}$ \\
\hline $\mathbf{0}$ & Immune & Nil & - \\
\hline 1 & $\begin{array}{l}\text { Highly } \\
\text { resistant }\end{array}$ & Nil & - \\
\hline 3 & $\begin{array}{l}\text { Moderately } \\
\text { resistant }\end{array}$ & ICG 1994,ICG 2734, ICG 4749, ICG 13856, ICG 7190 & 5 \\
\hline 5 & $\begin{array}{l}\text { Moderately } \\
\text { susceptible }\end{array}$ & ICG 4589, ICG 7181, ICG 7412, ICG 10094 & 4 \\
\hline 7 & Susceptible & $\begin{array}{l}\text { GKVK-5, GKVK-12, GKVK-17, ICG 1323, ICG 1326, ICG } \\
\text { 1435, ICG 1859, ICG 3120, ICG 3263, ICG 3336, ICG } \\
\text { 3700, ICG 4750, ICG 7000, ICG } 7243 \text {, ICG } 7633 \text {, ICG } \\
\text { 9610, ICG 10020, ICGV 91114 }\end{array}$ & 18 \\
\hline 9 & $\begin{array}{c}\text { Highly } \\
\text { susceptible }\end{array}$ & $\begin{array}{l}\text { AVK-2015-9, AVK-2015-12, ISK-2014-15, ISK-1-2015-5, } \\
\text { ISK-1-2015-8, ISK-1-2015-9, ISK-1-2015-10, ISK-1-2015- } \\
\text { 11, ICG 87264, ICG 95419, ICG 1173, ICG 2738, ICG 188, } \\
\text { ICG 4343, ICG 4389, ICG 4412, ICG 4527, ICG 4601, ICG } \\
\text { 4888, ICG 4998, ICG 6407, ICG 8666, ICG 9841, ICG } \\
\text { 10479, ICG 10933, ICG 11426, ICG 12370, ICG 14985, } \\
\text { ICGV 87165, ICGV 903021, GKVK-2, GKVK-4, GKVK- } \\
\text { 8a, GKVK-8b, KCG 6, KCG 9, TMV-2 }\end{array}$ & 37 \\
\hline \multicolumn{3}{|r|}{ Total No. of genotypes } & 64 \\
\hline
\end{tabular}

Table.5 Screening for cultivars against collar rot disease in field condition

\begin{tabular}{|c|c|c|c|c|}
\hline Sl.No. & Cultivars & Collar rot $^{*}(\%)$ & Disease reaction & ${\text { Pod yield }(\mathbf{q} / \mathbf{h a})^{*}}^{*}$ \\
\hline $\mathbf{1}$ & GKVK-5 & $1.70(1.48)$ & MR & $8.2(2.95)^{\mathrm{b}}$ \\
\hline $\mathbf{2}$ & K-9 & $1.70(1.48)$ & MR & $8.2(2.95)^{\mathrm{b}}$ \\
\hline $\mathbf{3}$ & KCG-6 & $1.70(1.48)$ & MR & $9.7(3.19)^{\mathrm{a}}$ \\
\hline $\mathbf{4}$ & TMV-2 & $2.30(1.67)$ & MR & $7.7(2.86)^{\mathrm{b}}$ \\
\hline $\mathbf{5}$ & GKVK-13 & $2.70(1.79)$ & MR & $8(2.95)^{\mathrm{b}}$ \\
\hline $\mathbf{6}$ & K-6 & $1.0(1.22)$ & MR & $10.5(3.32)^{\mathrm{a}}$ \\
\hline $\mathbf{7}$ & ICGV91114 & $1.30(1.34)$ & MR & $10.0(3.24)^{\mathrm{a}}$ \\
\hline $\mathbf{8}$ & GPBD-4 & $3.30(1.95)$ & MR & $7.6(2.85)^{\mathrm{b}}$ \\
\hline & F Test & NS & & $* *$ \\
\hline & S.Em \pm & 0.78 & & 0.48 \\
\hline & CD at $(0.05 \%)$ & 1.69 & & 1.04 \\
\hline
\end{tabular}

Figures in parentheses are arc sin angular transformed values 
Fig.1 Cultural and morphological characters of A. niger

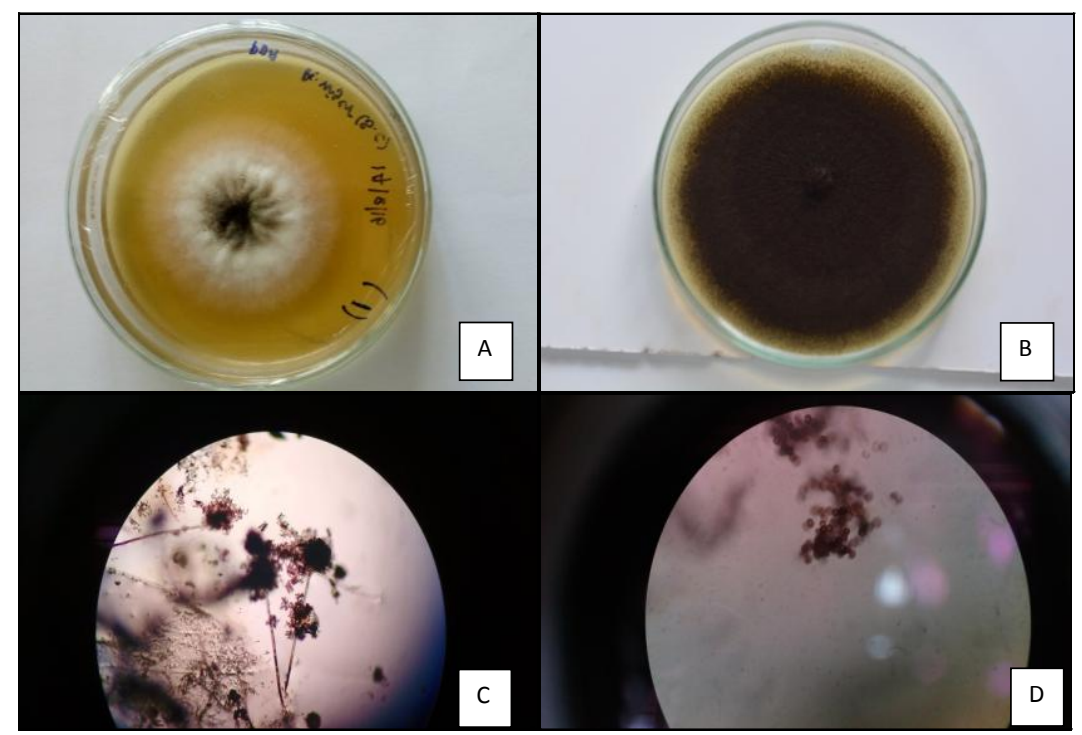

A. Initial white mycelial growth of A. niger on PDA

B. Colony turns into black colour upon sporulation

C. Microscopic view with complete structure of A. niger

D. Conidia brown in colour with rough surface

\section{Pathogenicity}

The Pathogenicity was conducted by sick pot method and blotter paper technique. Pathogenicity test was conducted by following artificial inoculation of soil with $A$. niger on susceptible groundnut cultivar TMV 2. The culture prepared by using sorghum seeds were inoculated to sick soil. The collar rot symptoms were observed at different stages of crop. Symptoms viz., pre-emergent seed rot, post-emergent seedling rot, collar rot at crown region of plant and finally death of the plant were recorded. Symptoms where the A. niger inoculated artificially were similar to that of the plants identified in the field condition. Re-isolation of the pathogen from artificially inoculated plant were compared with original culture of $A$. niger it was found to be similar with regards to all morphological characters on PDA.

Pathogenicity test was also performed in laboratory by blotter paper technique. Five infected seeds were placed at equidistance in Petri dishes for incubation. Re-isolation of the pathogen from infected seeds obtained were compared with original culture of $A$. niger, was found to be similar with respect to morphological characters on PDA.

\section{Screening for groundnut genotypes against collar rot disease}

Sorghum seeds were used for the multiplication of $A$. niger were mixed to sterilized soil and filled into sterilized pots. After two days each pot was sown with four seeds at equidistance. Different groundnut genotypes were screened for collar rot disease in sick pot maintained at glass house, Department of Plant Pathology, GKVK, Bengaluru during 2016-17 and field screening was done in ARS, Rajavanthi, Pavagada. The observations were recorded from date of sowing to maturity stage. The genotypes were categorized into disease reactions based on the disease incidence. 
Screening for genotypes against collar rot disease in glasshouse condition

Sixty four genotypes were screened for collar rot of groundnut and results are presented in Table 3. Among sixty four genotypes screened along with control for collar rot, five genotypes viz., ICG 1994, ICG 2734, ICG 4749, ICG 13856 and ICG 7190 showed moderately resistant reaction with 1-10 percent disease incidence, whereas four genotypes viz., ICG 4589, ICG 7181, ICG 7412 and ICG 10094 showed moderately susceptible reactions with (11-20\%) disease incidence, eighteen genotypes viz., GKVK- 5, GKVK-12, GKVK-17, ICG 1323, ICG 1326, ICG 1435, ICG 1859, ICG 3120, ICG 3263, ICG 3336, ICG 3700, ICG 4750, ICG 7000, ICG 7243, ICG 7633, ICG 9610, ICG 10020 and ICGV 91114 showed susceptible reaction with $(21-50 \%)$ disease incidence, remaining thirty seven genotypes viz., AVK-2015-9, AVK-2015-12, ISK-2014-15, ISK- 1-2015-5, ISK-1-2015-8, ISK-1-2015-9, ISK-1-2015-10, ISK-1-2015-11, ICG 87264, ICG 95419, ICG 1173, ICG 2738, ICG 188, ICG 4343, ICG 4389, ICG 4412, ICG 4527, ICG 4601, ICG 4888, ICG 4998, ICG 6407, ICG 8666, ICG 9841, ICG 10479, ICG 10933, ICG 11426, ICG 12370, ICG 14985, ICGV 87165, ICGV 903021, TMV-2, GKVK-2, GKVK-4, GKVK-8a, GKVK-8b, KCG 6 and KCG 9 showed highly susceptible reaction with disease incidence of 51-100 percent, whereas control was free from disease (Table 4).

\section{Screening for groundnut cultivars against collar rot disease in field condition}

Eight cultivars were screened for collar rot and results are presented in Table 5. Among eight cultivars screened for collar rot of groundnut, all of them were showed moderately resistant reaction with (1-10\%) disease incidence. Cultivar K-6 recorded highest pod yield of $10.5 \mathrm{q} / \mathrm{ha}$ followed by
ICGV 91114 (10.0 q/ha), KCG-6 (9.7 q/ha), GKVK -5 and K-9 (8.2 q/ha), GKVK-13 (8.0 q/ha), TMV-2 (7.7 q/ha) and GPBD-4 (7.6 q/ha). Three cultivars viz., ICGV 91114, KCG-6 and GKVK-5 were showed susceptible to disease in pot studies, whereas, they showed moderately resistance reaction, due to the inoculum load in the natural field condition as well as the performance of the cultivar in the field condition.

Collar rot is caused by Aspergillus niger van Teighem is one of the most important disease of groundnut which is more extensive in the kharif than the rabi and summer season and is now becoming serious threat to groundnut production recently (Desai and Bagwan, 2005). As per literature reviewed and there is a need to generate the detailed investigations on certain aspects of collar rot of groundnut. Investigations were carried out in respect to survey for disease incidence, isolation, identification of the pathogen and pathogenicity, screening of groundnut genotypes and the results are discussed here.

Collar rot disease incidence was highest in Tumkur (14\%) followed by Chamarajanagar (8.50\%), Chitradurga (6.40\%), Chikkaballapur (6.15\%) and Kolar (3.30\%) in Kharif season. The 3.3 percent disease incidence was recorded in Davangere during summer. The results were conformity with findings of Surekha Prabhu (1991) who recorded occurrence of disease in Kolar and Chikkaballapur districts of southern Karnataka on different cultivars of groundnut. Kadam et al., (2011) also conducted field surveys of groundnut in the Marathwada region of Maharashtra and recorded maximum disease incidence $(17.8 \%)$ in Renepur, Tahsil and minimum disease incidence $(8.9 \%)$ in Nilanga. The same type of observation was recorded and which revealed that collar rot of groundnut varied from locality to locality due to different soil 
conditions, cultivars used, cultivation practices and environmental conditions prevailing over these tracts. The higher incidence may be due to exposure of chickpea plants to moisture stress conditions and high temperature (Kishore et al., 2007).

The causal organism of collar rot pathogen was isolated from diseased plants of groundnut by following standard tissue isolation method. The pure culture was obtained through hyphal tip culture, maintained on potato dextrose agar and stored in refrigerator for further studies.

These results are in conformity with earlier workers of Jackson (1962), Anderegg et al., (1976), Mohamed et al., (2012), Matloob and Juber (2014). A. niger culture plates showed initially white to yellowish felt-like mat of mycelia, quickly turned black as conidia produced aspergillin pigment during maturation. Conidiophore was without segmentation, vesicle was spherical, it was biserrate form and conidial characters like brown colour, rough texture were observed through compound microscope.

The results of the present investigations are inconformity with those observed by Okuda et al., (2000) and Diba et al., (2007). Visual observation on collar rot of groundnut plants was recorded at various stages of crop growth. Symptoms appeared from initial stage to maturation stage. Affected plants showed various types of symptoms viz., pre-emergent seed rot, post-emergent seedling rot, collar rot at crown region of plant followed by death of the plant. Similar symptomatic observations were made by several workers Morwood (1945), Jain and Nema (1952), Gibson (1953), Chohan (1965), Gajera et al., (2011), Rakholia et al., (2012). Pathogenicity test was performed by sick pot culture technique, collar rot symptoms were observed from 7-50 days after sowing. Symptoms consisted of pre-emergent seed rot, post-emergent seedling rot, collar rot at crown region of plant. Symptoms due to collar rot in potted plants inoculated with $A$. niger were similar to that in the field. Re-isolation of the pathogen from infected portion was made and pathogenic cultures obtained were compared with original culture of $A$. niger and found to be similar with findings of Sen and Kapoor (1975), Kataria and Grover (1976), Radhakrishanan and Sen (1985) and Ramakrishna and Kolte (1989).

In laboratory pathogenicity was proved by blotter paper technique. After seven days of inoculation, the seeds were covered by black spores, emerged seedlings were rotted finally death of the seedlings were occurred. Reisolation of the pathogen from infected portion was made and pathogenic cultures obtained was compared with original culture of $A$. niger and found to be similar with the findings of Guptha and Chohan (1970), Mercer and Kisyambe (1978), Shim et al., (1996) and Cavallo et al., (1994). The utilization of resistant varieties is a classical approach to prevent the catastrophic losses caused by collar rot it reduces the cost of production and increase yield. Keeping this in view, investigation on performance of groundnut genotypes against collar rot disease under sick pot condition and field conditions were under taken. Among sixty four genotypes screened for collar rot five genotypes viz., ICG 1994, ICG 2734, ICG 4749, ICG 13856 and ICG 7190 showed moderately resistant reactions, whereas four genotypes viz., ICG 4589, ICG 7181, ICG 7412 and ICG 10094 showed moderately susceptible reactions, eighteen genotypes showed susceptible reaction and thirty seven genotypes showed highly susceptible reaction. None of the genotypes showed immune and resistant reaction under glasshouse condition. Among eight cultivars screened for collar rot of groundnut in field condition, all of them 
were showed moderately resistant reaction disease incidence. Cultivar K-6 recorded least per cent disease incidence $(1.0 \%)$ and highest pod yield of $10.5 \mathrm{q} / \mathrm{ha}$, TMV-2 and GPBD-4 recorded more per cent disease $(2.3 \%$ \& $3.3 \%)$ with least pod yield of $(7.7 \mathrm{q} / \mathrm{ha})$ and (7.6 q/ha) respectively. Similarly Mehan et al., (1987), Dasgupta and Raj (1997), Bhatia and Gangopadhyay (1996), Gaur and Singh (1993) and Sarawat et al., (2004) reported resistant genotypes, moderately resistant genotypes, moderately susceptible genotypes, susceptible genotypes and highly susceptible genotypes for collar rot disease with varying level of yield.

\section{References}

Anderegg RJ, Biemann K, Buechi G Cushman M (1976) Malformin C, a new metabolite of Aspergillus niger. J American Chem Soc 98: 3365-3370.

Anonymous (2014) Oilseeds situation - A statistical compendium, International Crops Research Institute for the SemiArid Tropics, Patancheru, India.

Bhatia JN, Gangopadhyay S (1996) Sources of resistance to collar rot and leaf spots of groundnut in Rajasthan. Indian $\mathbf{J}$ Mycol Plant Pathol 26(1): 108-109.

Cavallo AR, Novo RJ, Robledo CW (1994) Fungi reported from peanut seed (Arachis hypogaea L.) in Cordoba province, Argentina. Agri Sci 11: 43-48.

Chahal AS, Dutt S, Chohan JS (1974) Varietal resistance in groundnut (Arachis hypogaea L.) to collar rot (Aspergillus niger) in Punjab state. J Res Punjab Agri Univ 11(2): 200-203.

Chohan JS (1965) Bioassay of fungicides against Aspergillus niger van Tieghem. J Res Punjab Agri Univ 2(1): 25-32.

Dasgupta S, Raj SK (1997) Screening of groundnut germplasm for resistance to seed rot and collar rot diseases caused by Aspergillus niger. Int Arachis Newsl 17: 11-13.

Desai S, Bagwan NB (2005) Fungal Diseases of Rapeseed-Mustard. In: Dis. Oilseed
Crops. Indus Publishing Co., New Delhi, India. pp. 108-149.

Diba K, Kordbacheh P, Mirhendi SH, Renzaie S, Mahmoud M (2007) Identifications of Aspergillus species using morphological characteristics. Pak J Med Sci 23: 867872.

Gajera H, Rakholiya K, Vakharia D (2011) Bioefficacy of Trichoderma isolates against Aspergillus niger van Tieghem inciting collar rot in groundnut (Arachis hypogaea L.). J Plant Protec Res 51(3): 240-247.

Gaur RB, Singh RD (1993) Testing of groundnut genotypes against Aspergillus niger under artificial inoculation. Int Arachis Newsl 13: $15-17$.

Gibson IAS (1953) Crown rot seedling diseases of groundnut caused by A. niger and effect of orange mercurial seed dressings. Trans British Mycol Soc 36: 324- 334.

Gupta VK, Chohan JS (1970) Seed-borne fungi and seed health testing in relation to seedling diseases of groundnut. Indian Phytopathol.

Jackson CR (1962) Aspergillus crown rot of peanuts in Georgia, seed treatment fungicides for control of seedborne fungi in peanut. Plant Dis Rep 46: 888.

Jain AC, Nema KG (1952) Aspergillus blight of groundnut seedlings. Sci. Cult., 17: 348349.

Jochem SCJ (1926) Aspergillus niger on groundnut. Indisch Culturen (Teysmannia) 11: 325-326.

Kadam TS, Khalikar PV, Nikam PS (2011) Survey and surveillance of collar rot of groundnut caused by Sclerotium rolfsii in Marathwada region. J Plant Dis Sci 6(2): 204-205.

Kataria HR, Grover RK (1976) Some factors affecting the control of Rhizoctonia solani by systemic and non-systemic fungicides. Ann Appl Biol 82: 264-278.

Kishore GK, Pande S, Harish S (2007) Evaluation of essential oils and their components for broad-spectrum antifungal activity and control of late leaf spot and crown rot diseases in peanut. Plant Dis 91: 375-379.

Krishnakanth A, Gowda MVC, Motagi BN (1999) Response of spanish groundnuts to stem 
and pod rots caused by Sclerotium rolfsii Sacc. Int Arachis Newsl., 19: 27-28.

Matloob AAH, Juber KS (2014) First report of peanut crown rot disease caused by Aspergillus niger in Iraq and its biocontrol. J Expen Biol Sci., 2(2): 171-177.

Mayee CD, Datar VV (1986) Diseases of groundnut in the tropics. Rev Trop Plant Pathol., 5: 85-118.

Mehan VK, McDonald D, Rajagopalan K (1987) Resistance of peanut genotypes to seed infection by Aspergillus flavus in field trials in India. Peanut Sci., 14(1): 17-21.

Mercer PC, Kisyombe CT (1978) The fungal flora of groundnut kernels in Malwi and the effect of seed dressing. PANS., 24: 35-42.

Mohamed WGM, Zayed MAA, El-Kader DA (2012) Peanut pod and seed rots caused by Aspergillus spp. and their control. Zagazig J Agri Res., 39(2): 167-179.

Morwood RB (1945) Peanut diseases. Queensland Agri J., 6(1): 266-271.

Muthukumar A, Naveenkunar R, Venkatesh A (2014) Efficacy of Water Extracts of Some Mangrove Plants for Eco-friendly Management of Root Rot Disease of Groundnut. J Plant Pathol Microb 5: 243.

Okuda T, Maren AK, Keith AS, Katsuhiko A (2000) Media and incubation effects on morphological characters of penicillium and aspergillus. Tamagawa Univ., pp. 83100.

Palaiah PT, Narendrappa, Mallesh SB (2019) Screening of Groundnut Varieties and Germplasm against Collar rot, Stem rot and Dry Root rot Diseases. Int J Curr Microbiol App Sci., 8(6): 2321-2328.

Pattee HE, Young CY (1982) Peanut science and technology. American Peanut Research and Education Society Inc., Yoakum, pp. 655-687.

Radhakrishnan P, Sen B (1985) Efficacy of different methods of Inoculation of fusarium oxysporum and $F$. solani for inducing wilt in muskmelon. Indian Phytopathol., 38(1): 70-73.

Rakholia KB, Jadeja KB, Parakhia AM (2012) Management of collar rot of groundnut through seed treatment. Int $\mathrm{J}$ Life Sci Pharma Res., 2(1): 62-66.

Ramakrishna N, Kolte SJ (1989) Seed rot and seedling blights of groundnut and their chemical control in Nainital region of Uttar Pradesh. Indian $\mathbf{J}$ Mycol Plant Pathol., 19(3): 311-312.

Sarawat P, Toomsan S, Sirichumpan V, Sansayavichai T (2004) Khon-Kaen-6: a new groundnut variety in Thailand. Int Arachis Newsl., 24: 26-27.

Sen B, Kapoor IJ (1975) Systemic fungicides for the control of wilt of peas. Indian Phytopathol., 2: 76-78.

Shew BB, Wynne JC, Beute MK (1984) Effect of crop management on the epidemiology of southern stem rot of peanut. Phyto Pathol., 74(5): 530-535.

Shim H, Lee D, Lee G, Yu S, Shim HK, Lee DK, Lee SS, Yu SH (1996) Fungi associated with seed and seedling diseases of peanut. RDA J Agril Sci Crop Protec., 38(1): 507575.

Surekha Prabhu K (1991) Studies on collar-rot of groundnut caused by Aspergillus niger van Tiegham. Ph.D. Thesis. UAS GKVK, Bangalore.

\section{How to cite this article:}

Vimal Kumar, C., M. Saifulla, Madem Gurivi Reddy, R. Naveenkumar and Prabhukarthikeyan, S. R. 2020. Occurrence, Pathogenicity and Assessment of Groundnut Genotypes Resistance to Aspergillus niger Inciting Collar Rot Disease. Int.J.Curr.Microbiol.App.Sci. 9(11): 874-886. doi: https://doi.org/10.20546/ijcmas.2020.911.105 